\title{
Out of hospital cardiac arrest: anything new from aging cities?
}

Durí D. ', Danielis M. ${ }^{2}$, Caggegi G. D. ${ }^{3}$, Pegani C. ${ }^{3}$,Trilló G. ${ }^{4}$, Cleva M. ${ }^{3}$, Rossini P. ${ }^{3}$, Peratoner A. ${ }^{3}$

2. REGIONE AUTONOMA FRIULI VENEZIA GIUIM

Azienda Sanitaria Universitaria
Anestesia e Rianimazione I, Dipartimento di Anestesia e Rianimazione,Azienda Sanitaria Universitaria Integrata di Udine

2Anestesia e Rianimazione 2, Dipartimento di Anestesia e Rianimazione,Azienda Sanitaria Universitaria Integrata di Udine

${ }^{3}$ Struttura Semplice Dipartimentale 118, Dipartimento Emergenza Urgenza ed Accettazione, Azienda Sanitaria Universitaria Integrata di Trieste

${ }^{4}$ SOS di dipartimento Eliambulanza regionale, Dipartimento di Anestesia e Rianimazione, Azienda Sanitaria Universitaria Integrata di Udine

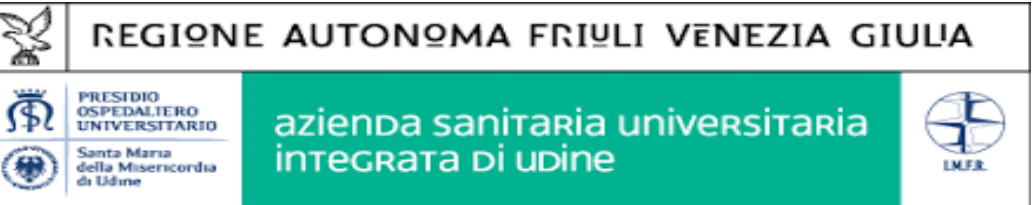

\section{Purpose of the study}

To investigate characteristics, treatments and outcomes amongst patients suffering out-of-hospital cardiac arrest (OHCA) in two cities, Udine and Trieste (Friuli Venezia Giulia, Italy), with different demographic features.

\section{Materials and methods}

All OHCA cases treated with cardiopulmonary resuscitation (CPR) by the Emergency Medical System (EMS) in the districts of Udine and Trieste from $01 / 01 / 2013$ to $31 / 12 / 2014$ were retrospectively included. Differences between the two communities and the EMSs are showed in Tables I and 2. Rescue time was defined as the interval from call to arrive at the scene of event Fisher's $t$ test or chi-squared test were used to analyse comparisons. A $P$ value of $<0.05$ was considered significant.

\section{Results}

Results are shown in Tables 3 and 4. Differences between the two areas were found in the number of patients with an initial shockable rhythm, in the rescue time and in the CPR duration. Moreover, statistically significant differences were recorded overall in the reasons for dispatching after the emergency telephone calls, in the priority colour code assigned by the dispatcher and in the initial rhythm of patients.

\section{Conclusions}

In 2014 the city of Trieste was declared the second most aging city in Italy. Survival rates from OHCAs were generally poor and there were no differences between the two cities. However, in Trieste there were more shockable rhythms. As there is no difference in terms of OHCA patients' age between the two cities, we assume that CPR was not performed in some very elderly people who suffered from OHCA in Trieste, considering the different ageing index of the population. In spite of a major number of vehicles available on day and night, rescue time was longer in Trieste, probably reflecting the complexity of a city road system, which may affect planning and deployment of EMS. Table I

\begin{tabular}{|c|c|c|c|c|c|}
\hline & (mm2) & (1) & per Knale) & $\%$ population $765 \mathrm{y}$ & ing inde \\
\hline Udine metropolitan area & 291,5 & 170891 & 586,2 & 24.3 & 196.8 \\
\hline Trieste metropolitan area & 212,5 & 235700 & 1109,1 & 28.3 & 248.9 \\
\hline taly & 302072,8 & 60782668 & 201,2 & 21.4 & 154.1 \\
\hline
\end{tabular}

Table 2

\begin{tabular}{|c|c|c|c|c|}
\hline & EMS dispatch site $8-20$ & EMS dispatch site $20-8$ & EMS team 8.20 & EMS team 2 \\
\hline Udine & 1 & 1 & $1 \mathrm{MT}, 2 \mathrm{ALS}, 1 \mathrm{BLS}$ & $1 \mathrm{MT}, 1 \mathrm{ALS}, 1 \mathrm{BLS}$ \\
\hline Trieste & 6 & 3 & $1 \mathrm{MT}, 4 \mathrm{ALS}, 3 \mathrm{BLS}$ & $1 \mathrm{MT}, 2 \mathrm{ALS}, 2 \mathrm{BLS}$ \\
\hline
\end{tabular}

Table 3

\begin{tabular}{|c|c|c|c|c|}
\hline & UDINE & TRIESTE & test & p \\
\hline patients number & 213 & 249 & & \\
\hline sex F, n. & 77 & 94 & chisquare & 0.948 \\
\hline age (mean, 1-2-3:-3 quartile) & $73,64-78-86$ & $72.2,65-74-84$ & fisher & 0.248 \\
\hline Rosc, n. & 64 & 73 & chisquare & 0.864 \\
\hline n. patients shock administered & 52 & 96 & chisquare & 0.001 \\
\hline $\begin{array}{l}\text { n. patients alive at discharge } \\
\text { from hospital }\end{array}$ & $18(8.4 \%)$ & $22(8.8 \%)$ & chisquare & 0.883 \\
\hline $\begin{array}{l}\text { rescue time (min, mean, 1-2-3 } \\
\text { quartile) }\end{array}$ & $9.8,6.9-912$ & $11.6,7-10-14)$ & fisher & 0.001 \\
\hline $\begin{array}{l}\text { CPR time (min., mean, 1-2-3 } \\
\text { quartile) }\end{array}$ & $28.6,20-26-36$ & 24.1 12-22-33 & fisher & 0.001 \\
\hline
\end{tabular}

Table 4

\begin{tabular}{|c|c|c|c|c|c|}
\hline $\begin{array}{l}\text { Dispatch } \\
\text { Cardicare }\end{array}$ & & & & chi square & 0.001 \\
\hline $\begin{array}{l}\text { chest pain } \\
\text { ches }\end{array}$ & 18 & 8 & 26 & & \\
\hline respiratory distress & ${ }_{37}$ & 47 & 84 & & \\
\hline lost to fonssciousness & 47 & 62 & 109 & & \\
\hline neurologic & 13 & 11 & 24 & & \\
\hline $\begin{array}{l}\text { trauma } \\
\text { hypogilicemia }\end{array}$ & $\begin{array}{l}15 \\
1\end{array}$ & $\begin{array}{l}10 \\
4\end{array}$ & $\begin{array}{l}25 \\
25\end{array}$ & & \\
\hline suicide & 2 & 1 & 3 & & \\
\hline $\begin{array}{l}\text { unknow } \\
\text { other }\end{array}$ & $\begin{array}{l}4 \\
13\end{array}$ & $\begin{array}{l}27 \\
23\end{array}$ & $\begin{array}{l}31 \\
36\end{array}$ & & \multirow{3}{*}{0.009} \\
\hline $\begin{array}{l}\text { Code } \\
\text { white }\end{array}$ & 3 & 1 & 4 & \multirow{2}{*}{ chisquare } & \\
\hline $\begin{array}{l}\text { green } \\
\text { vellow }\end{array}$ & 10 & 14 & 24 & & \\
\hline & $\begin{array}{l}82 \\
117\end{array}$ & $\begin{array}{l}132 \\
102\end{array}$ & $\begin{array}{l}214 \\
219\end{array}$ & \multirow{3}{*}{ chisquare } & \multirow{3}{*}{0.004} \\
\hline $\begin{array}{l}\begin{array}{l}\text { First rhyythm } \\
\text { asystole }\end{array} \\
\text { a }\end{array}$ & 121 & 96 & 217 & & \\
\hline pulseless electrical activity & 54 & 93 & 147 & & \\
\hline ventricular fibrillation & 35 & 54 & 89 & & \\
\hline ventricular tachycardia & 2 & 4 & 6 & & \\
\hline not reported & 1 & 2 & 3 & & \\
\hline
\end{tabular}

